Environment Conservation Journal 15(3) 71-79, 2014

ISSN 0972-3099 (Print) 2278-5124 (Online)

Abstracted and Indexed

\title{
Floristic analysis of Chiktan Valley in Kargil district, Jammu and Kashmir
}

\author{
Anil K. Raina $\bowtie$ and Abdul Hamid
}

Received:15.05.2014

Revised: 25.07 .2014

Accepted:03.08.2014

\begin{abstract}
Floristic analysis has been carried out separately for the plain area on the sides of a small stream (Kangi nallah) and mountainous region flanking the stream on both the sides in Chiktan valley of Kargil district in Ladakh region of J\&K. A total of 79 plant species belonging to 65 genera and 36 families were recorded from the whole study area which included 48 species (40 herbs and 8 shrubs) from the plain area and 37 species (18 herbs and 19 shrubs) from the mountainous area. Six species had exhibited their presence in both the plain as well as the mountainous region. There were 23 families which were monotypic i.e. these are represented by single genera and single species in the area. Asteraceae has been found to be the dominant family with 16 species and 14 genera followed by Fabaceae (8 species and 7 genera) and Rosaceae (7 species and 3 genera). Dominant genera present in the area are Potentilla with 4 species followed by Draba and Pedicularis (3 species each). Analysis of floristic composition further revealed that the ratio of family to genera is 0.55 , family to species is $\mathbf{0 . 4 5}$ and genera to species is $\mathbf{0 . 8 2}$. Comparison of diversity indices of the two regions showed that species richness and dominance is more in plain region and species diversity is more in mountainous region.
\end{abstract}

Keywords: Chiktan valley, Diversity indices, Floristic analysis, Kargil, Kanji nallah, Ladakh

\section{Introduction}

India - a land of physical, cultural, social and linguistic diversity has enormous biological diversity; as a result it is regarded as one of the seventeen mega biodiversity countries of the world. With only $2.4 \%$ of the world's area, India accounts for $7-8 \%$ of the world's recorded plant (about 45,000 , of which approximately 15,000 are of known medicinal value) and animal species (about 91,000). About 5,150 plant species (33\%) and 1,837 animal species are endemic to India (MoEF, 2010). Ladakh, the cold desert, is located between the Greater Himalaya in the south- east and the Karakoram Range in the north. The cold desert of Ladakh is characterised by prolonged sub zero temperature, low annual precipitation mostly in the form of snow, less fertile sandy soil with very low water holding capacity, sparsely distributed plant diversity, high insolation, rugged terrain, low humidity (<30\%), low oxygen, and high wind velocity. The plants of this zone show an adaptation to these conditions and are generally dwarfed, Author's Address

Deptt of Environmental Sciences, University of Jammu, Jammu

E-mail:anilkraina@yahoo.com stunted, woolly or spiny and develop a mosaic patch of different forms (Rhoades and Thompson, 1975; Walker et al., 1994). The plants are dominated by herbs followed by shrub and bushes. The plants start to grow towards the end of harsh winter when there is abundant sunlight and moisture. There is a short vegetative span ranging from several days to a few months (Bowman and Damm, 2002). The trans-Himalayan (Western Himalaya and Eastern Himalaya) region are considered as one of the most ecologically fragile bio geographic zones in India as the species there are highly vulnerable (Rodgers and Panwar, 1988). They are potentially under threat of biodiversity loss from global warming and unscientific exploitation (Sharma et al., 2010; La Sorte and Jetz, 2010). The present study has been carried out in Chiktan Valley of Kargil district which constitutes one of the administrative sub division of the district. Chiktan has a population of around 5,500 with a relatively decent literacy rate. The total area of the block is around 12 square kilometer. The whole block consists of six villages namely Khangral, Samrah, Chiktan, Hagnis, Shaker and then Sanjak which are situated at regular intervals 
after about every 1 to $1.5 \mathrm{~km}$ on the banks of a small stream called Kanji Nallah surrounded on both the sides by medium and large undulating hilly slopes. The stream originates from a small glacier located in Kanji/Hinaskut wild life sanctuary which falls under the jurisdiction of Khangral village on the Kargil- Leh highway NH-1D and after passing through these villages joins river Indus at village Sanjak (Fig. 1).Although the district combines the condition of both arctic and desert climate yet the climate of this valley can be divided into three micro climate viz severe cold and dry climate of Khangral, relatively mild climate of Chiktan, Samrah, Hagnis and Shaker and relatively warm climate of Sanjak with fertile soil. Chiktan valley has not been explored for its floristic elements. However, few studies on phytodiversity have been carried out in other similar region by Srivastava (2010), Shaheen et al., (2011) and Khan et al.,
(2012). Therefore, present attempt has been made to explore phytodiversity of the area.

\section{Material andMethods}

Chiktan Valley $\left(34^{\circ} 22^{\prime} 33.4^{\prime \prime}-34^{\circ} 34^{\prime} 45.7^{\prime \prime} \mathrm{N}\right.$ latitude and $76^{\circ} 31^{\prime} 22^{\prime \prime}-76^{\circ} 31^{\prime} 43.79^{\prime \prime} E$ longitude), located on left side of Kargil-Leh highway near Kanji/Hinaskut Wildlife sanctuary, is about half kilometer wide and traversed by Kanji Nallah which is flanked on both sides by medium and large undulating hilly slopes. For studying the floristic composition of the area, a number of field trips were undertaken from July to September 2012 and also repeated in 2013 to cover all the possible habitats. Plant species have been collected and compiled separately for the plain area on the sides of the stream (Kanji nallah) and mountainous region flanking the stream on both the sides of the valley.

Fig. 1: Location map of study area

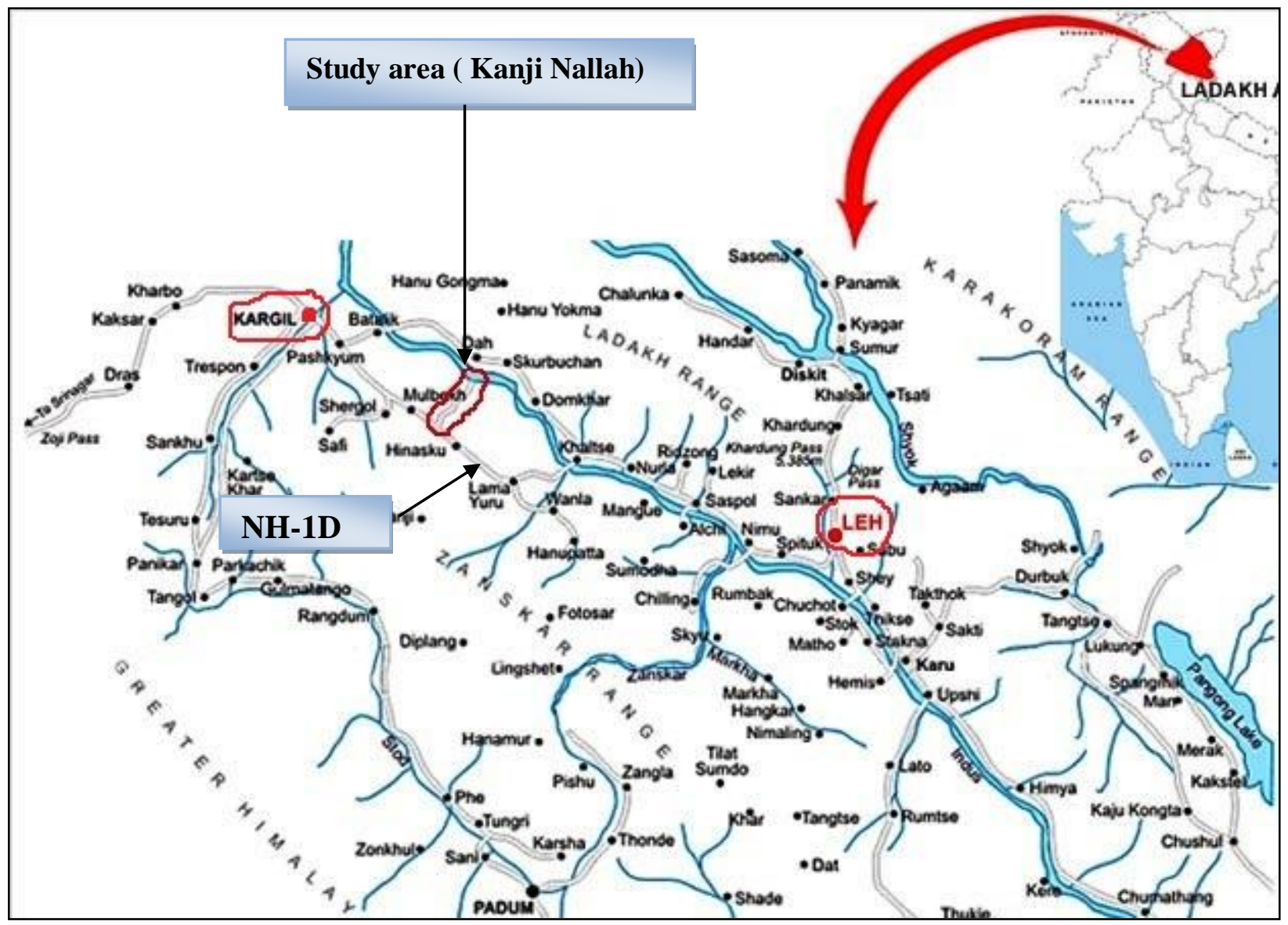

72

Environment Conservation Journal 
Plants have also been photographed to depict floral status. Diversity indices which helps in secondary analysis of the vegetation was calculated using Margalef's Index(1968), Menhinick's Index (1964), Simpson's Index (1949) and Shannon and Wiener index (1949). The index of similarity between the two regions has been calculated using Sorenson's index (1948) and Jaccard index (1901). For the purpose of identification of plants, various local, regional and national floras and herbarium were used besides consulting taxonomic experts of the region. Majority of the plants were identified by their vernacular names with the help of village elders.

\section{Results and Discussion}

The plant species recorded from the study region has been depicted in Table -1. No tree has been observed in the area. Herb and Shrub species recorded separately for the plain as well as mountainous region of the study area have been depicted in tables 2 to 5 with their vernacular names and family names. The perusal of table 1 revealed the presence of 79 species belonging to 65 genera and 36 families. Asteraceae has been found to be the dominant family with 16 species and 14 genera followed by Fabaceae ( 8 species and 7 genera) and Rosaceae (7 species and 3 genera).

Table 1: Total number of family, genera and species present in Chiktan valley

\begin{tabular}{|c|c|c|c|}
\hline S. No & Family & Genera & Species \\
\hline 1. & Alliaceae & 1. Allium & 1. A. przewalskianum Regel \\
\hline 2. & Apiaceae & 2. Tetrataenium & 2. T. pinnatum (C.B.Clarke) Manden \\
\hline \multirow[t]{16}{*}{3.} & \multirow{16}{*}{ Asteraceae } & 3. $\quad$ Cirsium & 3. C. $\operatorname{arvense}(\mathrm{L}$.$) Scop.$ \\
\hline & & 4. Taraxacum & 4. T. officinale Webb \\
\hline & & 5. Scorzonera & 5. S. virgata $\mathrm{DC}$ \\
\hline & & 6. Echinops & 6. E. cornigerus DC \\
\hline & & 7. Cichorium & 7. $\quad$ C. intybus $\mathrm{L}$. \\
\hline & & \multirow[t]{2}{*}{ 8. $\quad$ Aster } & 8. A. flaccidus Bunge \\
\hline & & & 9. A. molliusculus (Lindl. ex DC.) C.B.Clarke \\
\hline & & 9. Ajania & 10. A. tibetica (Hook.f. \& Thomson) Tzvelev \\
\hline & & \multirow[b]{2}{*}{ 10. Artemisia } & 11. A. gmelinii Weber \\
\hline & & & 12. A.stracheyi Hook.f. \& Thomson ex C.B.Clarke \\
\hline & & 11. Leontopodium & 13. L. jacotianum Beauverd \\
\hline & & 12. Pyrethrum & 14. P. pyrethroides (Kar. \&Kir.) B.Fedtsch. ex Krasch. \\
\hline & & 13. Inula & 15 I. racemosa Hook.f. \\
\hline & & 14.Saussurea & 16. S. heteromalla (D.Don) Hand.-Mazz. \\
\hline & & 15.Cousinia & 17. C. thomsonii C.B.Clarke \\
\hline & & 16 Anaphalis & 18. A.triplinervis(Sims) C.B.Clarke \\
\hline \multirow[t]{3}{*}{4.} & Boraginaceae & 17 Arnebia & 19. A. euchroma (Royle) I.M.Johnst. \\
\hline & & 18 Cynoglossum & 20 C.wallichiivarglochidiatum \\
\hline & & 19. Lindelofia & 21. L. stylosa (Kar. \&Kir.) Brand \\
\hline \multirow[t]{3}{*}{5.} & \multirow[t]{3}{*}{ Brassicaceae } & \multirow[t]{3}{*}{20 Draba } & 22. D. oreades Schrenk \\
\hline & & & 23. D. amoena O.E.Schulz \\
\hline & & & 24. D. gracillima Hook.f. \& Thomson \\
\hline 6. & Campanulaceae & 21.Codonopsis & 25. C. clematidea (Schrenk) C.B.Clarke \\
\hline 7. & Capparaceae & 22. Capparis & 26. C. spinosa $\mathrm{L}$ \\
\hline 8. & Caprifoliaceae & 23.Morina & 27. M. longifolia Wall \\
\hline \multirow[t]{2}{*}{9.} & \multirow[t]{2}{*}{ Caryophyllaceae } & 24.Silene & 28. S. indi var. edgeworthii ca \\
\hline & & 25.Arenaria & 29. A. kashmirica Edgew \\
\hline 10 & Colchicaceae & 26.Colchicum & 30. C. luteum Baker \\
\hline 11 & Compositae & 27.Anaphalis & 31. A. royleana $\mathrm{DC}$ \\
\hline 12 & Convolvulaceae & 28. Convolvulus & 32. C. arvensis $\mathrm{L}$. \\
\hline 13 & Crassulaceae & 29. Rhodiola & 33. R. fastigiata (Hook. f. \& Thomson) S.H. Fu \\
\hline 14 & Cupressaceae & 30.Juniperus & 34. J. macropoda Boiss \\
\hline 15 & Elaeagnaceae & 31.Hippophae & 35. H. rhamnoides $\mathrm{L}$. \\
\hline 16 & Ephedraceae & 32.Ephedra & 36. E. gerardiana Wall. ex Stapf \\
\hline \multirow[t]{2}{*}{17.} & \multirow[t]{2}{*}{ Fabaceae } & 33.Trigonella & 37. T. emodi Benth \\
\hline & & 34.Melilotus & 38. M. officinalis (L.) Pall. \\
\hline & & & 73 \\
\hline
\end{tabular}


Raina and Hamid

\begin{tabular}{|c|c|c|c|}
\hline & & 35.Lathyrus & 39. L. sativus L. \\
\hline & & 36.Trifolium & 40. T. repens $\mathrm{L}$. \\
\hline & & 37 A stragalus & 41. Astragulussps \\
\hline & & 3/.Astragalus & 42. A.rhizanthus Benth. \\
\hline & & 38Chesneya & 43. C.cuneata (Benth.) Ali \\
\hline & & 39. Oxytropis & 44. O. lapponica(Wahlenb.) Gay \\
\hline 18. & Fumariaceae & 40.Corydalis & 45.C. thyrsiflora Prain \\
\hline & & & 46.C. crassisima \\
\hline 19 & Gentianaceae & 41.Gentian & 47.G. kuroo \\
\hline 20 & Geraniaceae & 42.Geranium & 48.G. wallichianum D.Don ex Sweet \\
\hline & & & 49.G. pratense L. \\
\hline 21 & Grossulariaceae & 43Ribes & 50. R. orientale Desf. \\
\hline 22 & Iridaceae & 44.Iris & 51. I. lactea Pall \\
\hline 23 & Lamiaceae & 45.Nepeta. & 52. N. floccosa Benth \\
\hline & & 46.Marrubium & 53. M. vulgare L. \\
\hline & & 47.Thymus & 54. T. linearis Benth \\
\hline 24 & Leguminoseae & 48.Ciccer & 55. C. microphyllum Benth \\
\hline 25 & Onagraceae & 49.Epilobium & 56. E. latifolium L. \\
\hline 26 & Orchidaceae & 50.Dactylorhiza & 57. D. hatagirea (D.Don) Soó \\
\hline 27 & Orobanchaceae & 51.Pedicularis & 58. P. cheilanthifolia Schrenk \\
\hline & & & 59. P. pyramidata \\
\hline & & & 60. P. scullyana Prain ex Maxim. \\
\hline 28 & Plantaginaceae & 52.Plantago & 61. P. asiatica \\
\hline 29 & Plumbaginaceae & 53.Acantholimon & 62. Alycopodioides (Girard) Boiss. \\
\hline 30 & Polygonaceae & 54.Polygonum & 63. P. tortuosum D. Don \\
\hline & & 55. Oxyria & 64. O. digyna (L.) Hill \\
\hline & & 56.Rheum & 65. R. spiciforme Royle \\
\hline & & & 66. R. australe D. Don \\
\hline 31 & Ranunculaceae & 57.Ranunculus & 67. $R$. arvensis L. \\
\hline & & 58.Clematis & 68. C. tibetana Kuntze \\
\hline 32 & Rosaceae & 59.Potentilla & 69. P. bifurca L. \\
\hline & & & 70. P. anserina L. \\
\hline & & & 71. Potentilla \\
\hline & & & 72. P. eriocarpa Wall. exLehm. \\
\hline & & 60.Rosa & 73. R. webbiana Wall. ex Royle \\
\hline & & & 74. R. foetida Herrm. \\
\hline & & 61. Cotoneaster & 75. C. microphyllus Wall. Ex Lindl. \\
\hline 33 & Scrophulariaceae & 62.Verbascum & 76.V thapsus $\mathrm{L}$ \\
\hline 34 & Solanaceae & 63.Physochealta & 77. P. praealta (Decne.) Miers \\
\hline 35 & Tamaricaceae & 64.Myricaria & 78. M. germanica (L.) Desv. \\
\hline 36 & Urticaceae & 65.Urtica & 79.U. dioica $\mathrm{L}$. \\
\hline Total & 36 & 65 & 79 \\
\hline
\end{tabular}

Kumar (2009) has also recorded maximum number of species and genera for Asteraceae followed by Fabaceae in Suru Valley but for whole of Ladakh, Kachroo et al. (1977) although recorded maximum number of species and genera for Asteracea but it was followed by Brassicaceae rather than Fabaceae. There are 23 families which are monotypic i.e. these are represented by single genera and species in the area. Dominant genera of the study area have been found to be Potentilla with 4 species followed by Draba and Pedicularis (3 species each). Compilation of the herb and shrub species separately for the plain area adjoining the stream (Table 2 \& 3) and mountainous slopes (Table 4 \& 5) revealed the striking difference in the species distribution. The perusal of tables 2 and 3 revealed the presence of 40 herbs and 8 shrubs from the plain area adjoining the stream while from the mountainous slopes 18 herbs and 19 shrubs have been recorded (Table $4 \& 5$ ). Only six species viz Ajania tibetica, Cirsium arvenses, Echinopsis cornigerus, Physochlaina praealta, Rheum spiciforme and Verbascum thapsus 
Floristic analysis of Chiktan Valley in Kargil district

Table 2: Herbs of plain region of Chiktan valley

\begin{tabular}{|c|c|c|c|}
\hline S. No. & Species & Vernacular name & Family \\
\hline 1. & Allium przewalskianum Regel & & Alliaceae \\
\hline 2. & Aster flaccidus Bunge & & Asteraceae \\
\hline 3. & Aster molliusculus (Lindl. ex DC.) C.B.Clarke & & Asteraceae \\
\hline 4. & Cicer microphyllum Benth & & Leguminosae \\
\hline 5. & Cichorium intybus L. & Shantik & Asteraceae \\
\hline 6. & Cirsium arvense (L.) Scop. & Zbantser & Asteraceae \\
\hline 7. & Clematis tibetana Kuntze & kota & Ranunculaceae \\
\hline 8. & Codonopsis clematidea (Schrenk) C.B.Clarke & Faqfaq & Campanulaceae \\
\hline 9. & Colchicum luteum Baker & & Colchicaceae \\
\hline 10. & Convolvulus arvensis $\mathrm{L}$. & Thithimo & Convolvulaceae \\
\hline 11. & Corydalis thyrsiflora Prain & & Fumariaceae \\
\hline 12. & Dactylorhiza hatagirea (D.Don) Soó & Khirgma & Orchidaceae \\
\hline 13. & Draba amoena O.E.Schulz & & Brassicaceae \\
\hline 14. & Draba gracillima Hook.f. \& Thomson & & Brassicaceae \\
\hline 15. & Draba oreades Schrenk & & Brassicaceae \\
\hline 16. & Echinops cornigerus DC & Kaqtsaymaq & Asteraceae \\
\hline 17. & Gentian kurooL. & Huchung & Gentianaceae \\
\hline 18. & Geranium pratense $\mathrm{L}$. & & Geraniaceae \\
\hline 19. & Geranium wallichianum D.Don ex Sweet & Spoldo & Geraniaceae \\
\hline 20. & Iris lactea Pall & Tesma & Iridaceae \\
\hline 21. & Lathyrus_sativus L. & Garaz & Fabaceae \\
\hline 22. & Melilotus officinalis (L.) Pall. & Dannga & Fabaceae \\
\hline 23. & Oxyria digyna (L.) Hill & Shoma & Polygonaceae \\
\hline 24. & PedicularispyramidataRoyle ex Benth. & Logorgot & Orobanchaceae \\
\hline 25. & Pedicularisscullyana & & Orobanchaceae \\
\hline 26. & Pedicularis cheilanthifolia Schrenk & & Orobanchaceae \\
\hline 27. & Physochlaina praealta (Decne.) Miers & Lantang & Solanaceae \\
\hline 28. & Plantagoasiatica & Biazanma & Plantaginaceae \\
\hline 29. & Polygonum tortuosum D. Don & Tsanalo & Polygonaceae \\
\hline 30. & Potentilla anserina $\mathrm{L}$. & Totoma & Rosaceae \\
\hline 31. & Potentilla bifurca $\mathrm{L}$. & Spanktsemik & Rosaceae \\
\hline 32. & Ranunculus arvensis L. & Isman & Ranunculaceae \\
\hline 33. & Rheum spiciforme Royle & Latchu & Polygonaceae \\
\hline 34. & Scorzonera virgata $\mathrm{DC}$ & Tsarchan & Asteraceae \\
\hline 35. & Sileneindi var. edgeworthii ca & & Caryophyllaceae \\
\hline 36. & Taraxacum officinale Webb & Khorkhorma & Asteraceae \\
\hline 37. & Tetrataenium pinnatum (C.B.Clarke) Manden & Spisho & Apiaceae \\
\hline 38. & Trifolium repens $\mathrm{L}$. & & Fabaceae \\
\hline 39. & Trigonella emodi Benth & Bugsug & Fabaceae \\
\hline 40. & Verbascum thapsus $\mathrm{L}$. & & Scrophulariaceae \\
\hline
\end{tabular}


Table 3: Shrubs of plain region of Chiktan Valley

\begin{tabular}{|l|l|l|l|}
\hline S. No. & Species & Vernacular name & Family \\
\hline 1. & Arenaria kashmirica Edgew. & & Caryophyllaceae \\
\hline 2. & Arnebia euchroma (Royle) I.M.Johnst. & Demok & Boraginaceae \\
\hline 3. & Capparis spinosa L. & Kabra & Capparaceae \\
\hline 4. & Epilobium latifolium L. & & Onagraceae \\
\hline 5. & Hippophae rhamnoides L. & Tsokskure & Elaeagnaceae \\
\hline 6. & Myricaria germanica (L.) Desv. & Umbu & Tamaricaceae \\
\hline 7. & Rosa foetida Herrm. & Siasirpo & Rosaceae \\
\hline 8. & Rosa webbiana Wall. ex Royle & Siamarpo & Rosaceae \\
\hline
\end{tabular}

Table 4: Herbs of mountain region of Chiktan valley

\begin{tabular}{|l|l|l|l|}
\hline S. No. & Species & Vernacular name & Family \\
\hline 1. & Ajania tibetica (Hook.f. \& Thomson) Tzvelev & Phasbursey & Asteraceae \\
\hline 2. & Artemisia gmelinii Weber & & Asteraceae \\
\hline 3. & Astragulussps. & Dayrkal & Fabaceae \\
\hline 4. & Chesneya cuneata (Benth.) Ali & Bigangbo & Fabaceae \\
\hline 5. & Corydalis crassisima L. & Shapur & Fumariaceae \\
\hline 6. & Cynoglossumwallichiivarglochidiatum & & Boraginaceae \\
\hline 7. & Inula racemosa Hook.f. & Shorokmorok & Asteraceae \\
\hline 8. & $\begin{array}{l}\text { Leontopodiumjacotianum } \\
\text { Beauverd. }\end{array}$ & & Asteraceae \\
\hline 9. & Lindelofia stylosa (Kar. \&Kir.) Brand & Makpen & \\
\hline 10. & Nepeta floccosa Benth. & Shamalolo & Boraginaceae \\
\hline 11. & $\begin{array}{l}\text { Oxytropislapponica } \\
\text { (Wahlenb.) Gay }\end{array}$ & Rkamindok & Lamiaceae \\
\hline 12. & Potentilla spp. & Fabaceae \\
\hline 13. & Potentilla eriocarpa Wall. exLehm. & & \\
\hline 14. & Pyrethrum pyrethroides (Kar. \&Kir.) B.Fedtsch. ex Krasch. & Serpen & Rosaceae \\
\hline 15. & Rheum australe D. Don & Khakhol & Rosaceae \\
\hline 16. & Rheum spiciforme Royle & Latchu & Asteraceae \\
\hline 17. & Saussurea heteromalla (D.Don) Hand.-Mazz. & & Polygonaceae \\
\hline 18. & Verbascum thapsus L. & Shondok & Polygonaceae \\
\hline
\end{tabular}

Table 5: Shrubs of mountain region of Chiktan valley

\begin{tabular}{|c|c|c|c|}
\hline S. No. & Species & Vernacular name & Family \\
\hline 1. & Acantholimon lycopodioides (Girard) Boiss. & Longze & Plumbaginaceae \\
\hline 2. & Ajania tibetica (Hook.f. \& Thomson) Tzvelev & Phasbursey & Asteraceae \\
\hline 3. & Anaphalistriplinervis (Sims) C.B.Clarke & & Asteraceae \\
\hline 4. & Anaphalis royleana $\mathrm{DC}$. & kasboor & Compositae \\
\hline 5. & Artemisia stracheyi Hook.f. \& Thomson ex C.B.Clarke & nagsbur & Asteraceae \\
\hline 6. & Astragalus rhizanthus Benth. & Zbitchu & Fabaceae \\
\hline 7. & Cirsiumarvense (L.) Scop. & Zbantzer & Asteraceae \\
\hline 8. & Cotoneaster microphyllus Wall. exL indl. & Tsato & Rosaceae \\
\hline 9. & Cousinia thomsonii C.B.Clarke & pizum & Asteraceae \\
\hline 10. & Echinops cornigerus DC. & kaqtsaymaq & Asteraceae \\
\hline 11. & Ephedra gerardiana Wall. ex Stapf & Chappat & Ephedraceae \\
\hline 12. & Juniperus macropoda Boiss & Shukpa & Cupressaceae \\
\hline 13. & Marrubium vulgare $\mathrm{L}$. & yakzas & Lamiaceae \\
\hline 14. & Morina longifolia Wall. & & Caprifoliaceae \\
\hline 15. & Physochlaina praealta (Decne.) Miers & Lantang & Solanaceae \\
\hline 16. & $\begin{array}{l}\text { Rhodiola fastigiata (Hook. f. \& Thomson) } \\
\text { S.H. Fu }\end{array}$ & rtatrolo & Crassulaceae \\
\hline 17. & Ribes orientale Desf. & Askuta & Grossulariaceae \\
\hline 18. & Thymus linearis Benth & & Lamiaceae \\
\hline 19. & Urtica dioica $\mathrm{L}$. & Rdoastat & Urticaceae \\
\hline
\end{tabular}


have registered their appearance both in the plain areas as well as in the mountainous region leading to high species dissimilarity index. Analysis of floristic composition further revealed that the ratio of family to genera is 0.55 , family to species is 0.45 and genera to species is 0.82. Kumar (2009) recorded ratio of family to genera, family to species and genera to species to be $0.35,0.19$ and 0.53 respectively whereas the ratio of family to genera, family to species and genera to species recorded by Kachroo et al. (1977) for whole of Ladakh was $0.26,0.08$ and 0.31 , respectively. The overall finding shows that the number of species with respect to genera and family and the number of genera with respect to family increases with the increase in the area resulting in larger ratios in smaller areas and vice versa (Table 6). Besides primary analysis of vegetation using IVI, species can also be analyzed at secondary level which involves the use of, total species number and the total number of individuals. Shannon index tells about the species diversity which involves species richness and species evenness in a delineated community, Simpson index is used to find the dominance (increases with decrease in evenness) of species whereas Margalef's Index and Menhinick's Index is used to find out simply the richness of the species in the community which generally increases with increase in number of individuals. Secondary analysis of the plants using these four indices have been carried out for herbs, shrubs and the total (herbs+shrubs) plant species both in the plain as well as mountainous regions and are depicted in tables 7 and 8. Diversity indices of the plants (herbs+shrubs) of plain and mountainous regions have also been compared to find out the difference in species richness, evenness and dominance between the two communities (Table 9, Fig. 2).

Table 6: Comparison of Floristic Diversity of Chiktan valley with other areas

\begin{tabular}{|l|l|l|l|l|l|l|}
\hline Work done & F & G & S & Ratio (F:G) & Ratio (F:S) & Ratio (G:S) \\
\hline Kachroo et al. (1977) (Ladakh) & 51 & 190 & 611 & 0.26 & 0.08 & 0.31 \\
\hline Kumar (2009) (Kargil) & & & & & & \\
\hline Author (2013) (Chiktan) & 36 & 65 & 79 & 0.55 & 0.19 & 0.53 \\
\hline F = Family; G = Genera; S = Species
\end{tabular}

Table 7: Diversity indices of plain areas of Chiktan valley.

\begin{tabular}{|l|c|c|c|}
\hline \multicolumn{1}{|c|}{ Parameters } & Total species & Herbs & Shrubs \\
\hline Total number of Species & 48 & 40 & 8 \\
\hline Total number of individuals (N) & 5194 & 4766 & 428 \\
\hline Margalef's Index (Da) & 5.49 & 4.64 & 1.15 \\
\hline Menhinick's Index (Db) & 0.71 & 0.57 & 0.38 \\
\hline Simpson's Index (Ds) & 0.97 & 0.96 & 0.85 \\
\hline Shannon-Weiner's Index (H') & 3.67 & 3.52 & 1.98 \\
\hline
\end{tabular}

Table 8: Diversity indices of mountainous area of Chiktan valley.

\begin{tabular}{|l|l|l|l|}
\hline Parameters & Total Species & herbs & Shrubs \\
\hline Total number of Species & 37 & 18 & 19 \\
\hline Total number of individuals (N) & 2652 & 1182 & 1470 \\
\hline Margalef's Index (Da) & 4.56 & 2.40 & 2.46 \\
\hline Menhinick's Index (Db) & 0.67 & 0.52 & 0.49 \\
\hline Simpson's Index (Ds) & 0.96 & 0.93 & 0.92 \\
\hline Shannon-Weiner's Index (H') & 6.93 & 2.81 & 2.74 \\
\hline
\end{tabular}


Table 9: Comparison of diversity indices of plants of plain areas with that of mountainous areas.

\begin{tabular}{|l|l|l|}
\hline Parameter & Species of plain region & Species of mountainous region \\
\hline Margalef's Index $(\mathrm{Da})$ & 5.49 & 4.56 \\
\hline Menhinick's Index $(\mathrm{Db})$ & 0.71 & 0.67 \\
\hline Simpson's Index $(\mathrm{Ds})$ & 0.97 & 0.96 \\
\hline Shannon-Weiner's Index $\left(\mathrm{H}^{\prime}\right)$ & 3.67 & 6.93 \\
\hline
\end{tabular}

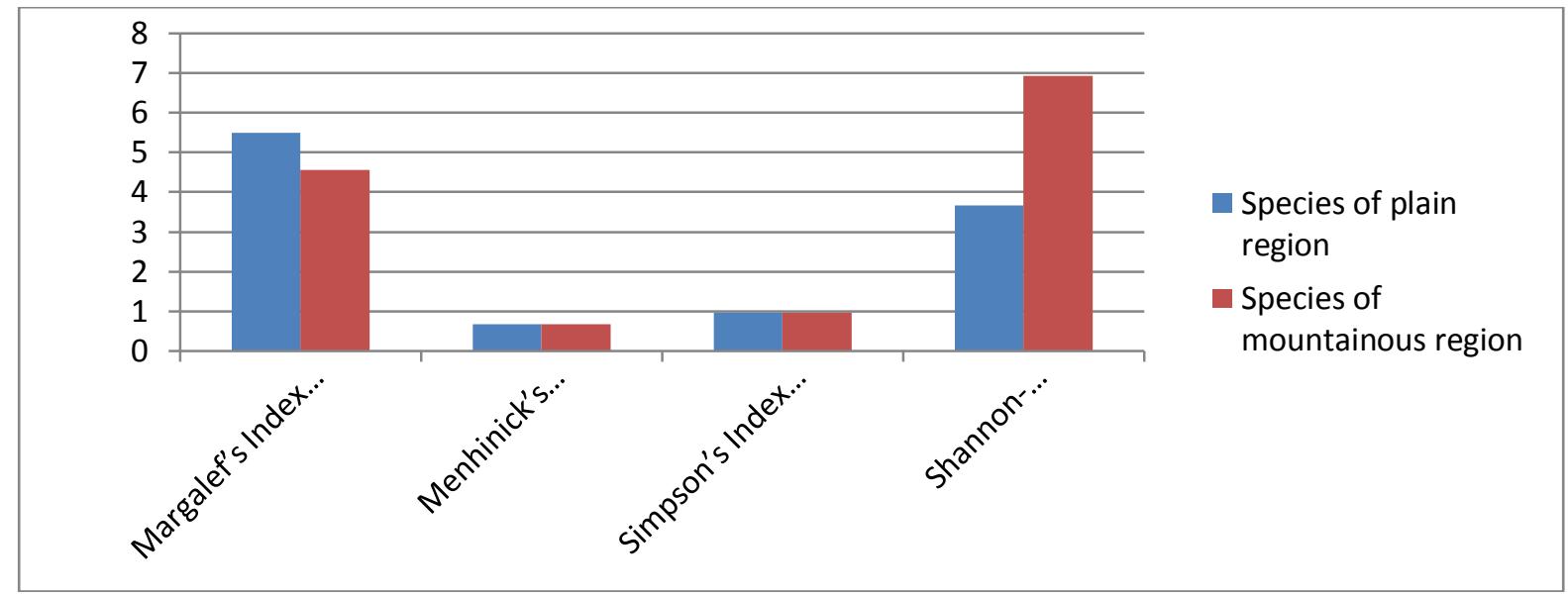

Fig. 2.Bar digram showing comparison of diversity indices of Species (herbs and shrubs) of plain region with species (herbs and shrubs) of Mountainous region.

Comparison of the values of diversity indices of the plain and mountain areas revealed that the overall species richness (Margalef's Index, Menhinick's Index) as well as dominance (Simpsons Index) is more in plain region than in mountainous region. Plain area is characterized by the presence of a large number of species (richness) in which some species have been found to be having a large number of individuals as compared to the rest of the species (dominance). In mountainous areas, the number of species is although small but each species have been found to be having more or less the same number of individuals (high evenness) as shown by the high value of Shannon index. Although when individual values for the Simpsons Index are observed, the species tend to show more dominance then evenness (values for Simpson index lies between zero and one and approaches one in the limit of a monoculture). The decrease in number of species with increasing altitude for various Himalayan ranges is a recognized pattern with certain variations in pattern (Korner, 2003). Severity of climatic conditions, trampling by humans and livestock grazing can be the factors behind the declined species richness on the mountains (Buntaine et al., 2007). However high evenness in the mountains can be attributed to the well demarcated and non-overlapping home range formed by the livestock and other grazing population over the years. Further on the slopes presence of a number of shrub species indicate their better tolerance to dry conditions. Since the study has been carried out in two adjoining but different communities, Jaccard's index and Sorenson's index have been used to find out the similarity index between the two regions. These two indices helps us to examine species variation with respect to distance or environmental differences between the sites. The value of these two indices varies from $0-1$, complete community overlap is equal to 1 and complete community dissimilarity is equal to 0 . The small values for these two indices (Table 10) show the high dissimilarity (low similarity) index between the two regions which may be due to the wide variation in climatic conditions between the two regions. 
Table 10: Index of similarity (Sorenson's index and Jaccard's index) between the plain and the mountainous region

\begin{tabular}{|c|c|c|c|c|}
\hline $\begin{array}{c}\text { No. of species in } \\
\text { Plain region }\end{array}$ & $\begin{array}{c}\text { No. of species in } \\
\text { mountainous } \\
\text { region }\end{array}$ & $\begin{array}{c}\text { Species common to } \\
\text { both regions }\end{array}$ & Sorenson's index & Jaccard's index \\
\hline 48 & 37 & 6 & 0.14 & 0.06 \\
\hline
\end{tabular}

\section{References}

Bowman, W. D. and Damm, M. 2002. Causes and consequences of vascular plant diversity in the Rocky Mountains. In: Korner Ch, Spehn EM (eds). Mountain Biodiversity: A Global Assessment. New York: The Parthenon Publishing Group, pp.35- 48 .

Buntaine, M. T., Mullen, R. B. and Lassoie, J. P. 2007.Human use and conservation planning in alpine areas of northwestern Yunnan, China. Environment, Development and Sustainability. 9: 305-324.

Jaccard, P. 1901. Distribution de la flore alpine dans le Bassin des Dransesetdans quelques regions voisines. Bull. Soc. vaud.Sci. nat. 37, 241-72.

Kachroo P, Sapru, B. L and Dhar, U. 1977. Flora of Ladakh: an ecological and taxonomic appraisal.Bishen Singh Mahendra Pal Singh, Dehradun, India.

Khan, S. M., Page, S., Ahmad, H., Shaheen, H.and Harper, D. 2012. Vegetation dynamics in the Western Himalayas, diversity indices and climate change. Science, Technology and Development. 31(3):232-243, 2012.

Korner. C. 2003. Alpine Plant Life In: Functional Plant Ecology of High Mountain Ecosystems, 2nd edn. Berlin, Germany: Springer-Verlag.

Kumar, R. 2009. Environmental Impact Assesment of Chutuk Hydroelectric Project on phytodiversity. Ph.D. thesis. University of Jammu, Jammu. (J\&K) India.

La Sorte, F. A. and Jetz, W. 2010. Projected range contractions of montane biodiversity under global warming. Proceedings of the Royal Society B: Biological Sciences. 277: $3401-3410$.

Margalef, R. 1968. Perspectives in Ecological Theory. University of Chicago Press.Chicago, pp. 111.

Menhinick, E. F. 1964. A Comparison of Some Species Diversity Indices applied to Samples of Field Insects. Ecology. 45: 858-862.
MoEF, 2010.India \& the convention on biological diversity (cbd) Cop-10. Nagoya,Japan.

Sorenson, T. 1948. A method of establishing groups of equal amplitudes in plant society based on similarity of species. Content. K. DanskeVidensk, Selask. 5:1-34.

Rhoades, R. E. and Thompson, S. I. 1975. Adaptive Strategies in Alpine Environments: Beyound Ecological Particularism. American Ethnologist. 2(3): 535-551.

Rodgers, W. A. and Panwar, H. S. 1988.Planing a Protected Area Network in India.The Report.Wildlife Institute of India. Dehra Dun.

Shannon, C. E. and Weiner, W. 1949.The Mathematical Theory of Communication.University of Illinois press, Urbana, USA.pp. 117.

Simpson, E. H. 1949. Measurement of diversity. Nature.163: 688.

Shaheen, H., Khan, S. M., Harper, D. M., Ullah, Z. and Qureshi, R. A. 2011. Species Diversity, Community Structure, and Distribution Patterns in Western Himalayan Alpine Pastures of Kashmir, Pakistan. Mountain Research and Developmen. 31(2):153-159. 2011.

Sharma, E., Chettri, N. and Oli, K. P. 2010. Mountain biodiversity conservation and management: a paradigm shift in policies and practices in the Hindu KushHimalayas. Ecological Research. 25: 909-923.

Srivastava, S. K. 2010. Floristic diversity and conservation strategies in cold desert of western Himalaya, India. Journal of Plant Science. 7: 18-25

Walker, M. D., Webber, P. J., Arnold, E. H., and Ebert-May, D. 1994. Effects of Interannual Climate Variation on Aboveground Phytomass in Alpine Vegetation. Ecology. 75(2): 393-408. 